\title{
Spiritual experiences in the marketplace: Why is it possible?
}

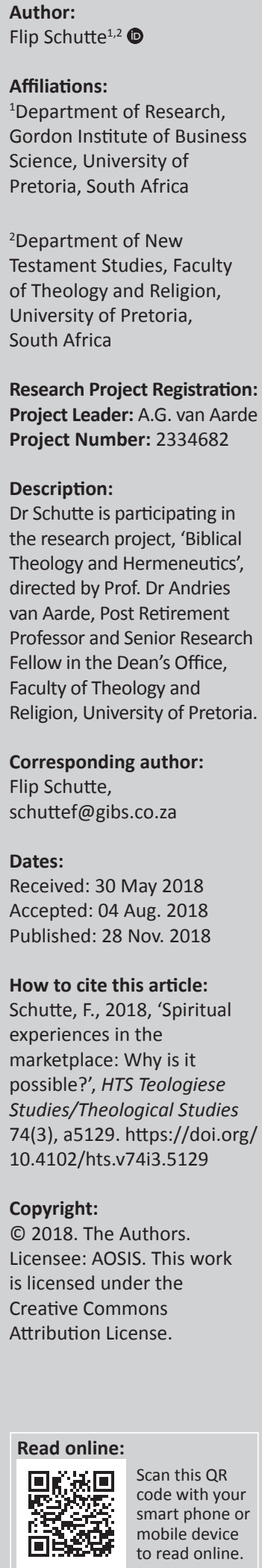

For some churches, declining attendance and membership numbers are a given. From a marketing and business perspective, churches are experiencing growing competition on a spiritual level from the world of business within the experience economy. It seems as if the church is slowly losing the battle. This is an opinion article based on original research and observing, discussing and reading about innovation within a market where the quest for experiences is growing.

\section{Creating context: Spirituality, consumers and marketing}

Over the past few years, the topic of spirituality has inspired many studies in management and related disciplines, but marketing scholars seemed to have shied away from discussing spirituality. The small amount of literature that does exist on spirituality and marketing tends to be confined to the marketing of churches, cults or religiously related articles, books, seminars, camps and counselling.

According to Kale (2006), spirituality revolves around the key constructs of meaning and interconnectedness. Spirituality has the potential to explain some of the dynamics between the self and consumption. Kale defined spirituality as an individual's endeavours to explore one's inner self to the known world and beyond and to connect with it in a deep and meaningful way. In the marketplace, spirituality is about delimiting the boundaries of traditional spirituality and creating post-secular and post-theistic (Van Aarde 2009) spiritual experiences that can be deep and meaningful for the consumer because it helps him or her to create the opportunity to connect to his or her inner self in a supportive atmosphere that is relaxing, different but not, not-from-this-world.

Spirituality is increasingly impacting the beliefs and behaviours of consumers. Spiritual motivations are not restricted to the choice of a particular sect, guru or religion. Secular corporate firms and exclusive niche organisations are increasingly using spiritual appeals to identify and bond with consumers.

\section{Background to the phenomenon}

Humans are a very interesting species. What distinguishes humans from other species is the fact that they create narratives, mostly fiction (Harari 2011). Then they move on to inhabit those narratives. According to Harari, money is a good example of creating fiction and allowing it to rule over you. Money only has value in our imagination because money is a piece of paper with a printed number on it. Humans have created a narrative around the value of that piece of paper. The narrative lives in our shared collective imagination and, because we all believe the fiction, money is ruling our world at the moment. It works the same with economic, political, ideological paradigms and spiritual concepts.

The fiction that humans create gives birth to processes. Then, humans become slaves of the processes they have created based on the fiction they have created. But, because as species humans also have cognitive and critical evaluation abilities, they rethink their fiction from time to time. They amend it and correct it. They eliminate parts thereof, ignore parts therein, and now and then they replace passages of their oeuvre with new fiction.

On a spiritual level, our ancestors became aware of the notion that maybe there exists somebody higher, different and more powerful than themselves. They discovered this idea when asking themselves: Where did everything come from? Who makes everything happen? Why do we not 
always understand life? Who causes the things that happen in our world? For a lot of things, they also did not want to take responsibility, so they blamed it on this higher being. They called this higher being God and they started creating narratives about how they understood God in relation to humans and their whereabouts.

They created narratives about how to live in a relationship with this God. They created narratives about this God's existence in a place called heaven and how he wanted to be treated and worshipped as a king. These narratives developed into processes which became rituals (Harari 2016). Some of the themes from their narratives became dogma within their sacred circles. Then they started creating narratives around these dogmas to ground their rituals and beliefs. And because their kings had castles, they decided to build a home for their God as well. But they did not call it a castle or a palace; instead, they called it a temple or a cathedral. They then created narratives on how to accommodate these buildings in their relationship with their God. And more dogma and narratives were conceptualised.

These buildings for their God became the centrum of their spiritual life just as the house of the landlord was the centre of agrarian life. They projected what humans do, to their pantheon, and assumed that the gods are doing it in the same manner.

\section{The problem: 'Change! Things always want to change! Why did consistency die?'}

Currently, the human species again is at a stage where the content of these narratives is starting to change. Humans are busy adjusting their master narrative. At times like these, where paradigms shift and new content is being created, new competition and role players enter the market to contest with the general and accepted master narrative. Only time will tell which narrative wins the contest and survives as the new master narrative.

One of the strong contestants at the moment to create new fiction and an alternative narrative is the marketplace. Because in the marketplace the eye and focus are set on a need, and to create a product to fulfil the need (Cant \& Van Heerden 2015). The marketplace is constantly looking for opportunities. They often find their opportunities in incongruities. According to Kuratko (2017), this is where a gap exists between expectations and reality. These incongruities give rise for a need to develop. The need can be seen as a type of 'pain' and the solution to the need is seen as the 'painkiller'. Once you have a solution or product for a need, you have a business. In the marketplace, nobody ever slumbers or sleeps and opportunists are looking for solutions to address needs.

Because it was tradition, and because the master narrative told people to go to church on a Sunday morning, they went.
But, currently, because of the postmodern hermeneutics of suspicion (Marcelo 2011), deconstruction, and the transformation of society away from a patriarchal autocratic driven environment, people are more aware of other options and the fact that they have a choice, so they do not necessarily do what tradition tells them to do.

On grassroots level, people are talking about and experimenting with a new type of spirituality, which is not part of mainstream popular culture and traditional church hierarchies. This type of spirituality is discussed and experienced, according to Forman (2004), in living rooms, church basements, yoga centres, nature walks, meditation rooms and coffee shops. It is a way of living in a post-theistic paradigm, discovering a new type of spirituality. Post-theistic, according to Van Aarde (2009), is a situation, as we have today, where different conceptualisations of the existence and nature of God still prevail, but where a postmodern way of thinking evolves as a critique on certain aspects of theism. Where people seek new meaning, and a new understanding of the self, and their engagement with the world in which they live, in this situation a new type of spirituality, which might be called a post-secular spirituality (Van Aarde 2009), is coming to the front. Within this environment where the master narrative regarding the relationship between God, men and church is being questioned the marketplace is creating rich and powerful experiences to try to satisfy the empty space in people's lives. The product or the service that the marketplace offers is an experience outside the domain of traditional religion, spirituality and church, where people can interact with their significant others, connect with themselves, and even find purpose again. This happens within the experience economy and marketplace! The marketplace is, thus, consciously offering an alternative, which consumers can interpret as spiritually meaningful to them, and in that sense, the marketplace becomes competition for the church.

According to the webpage 'Church Statistics 2017', more than $85 \%$ of American churches have steadily declined over the past 30 years. Almost $59 \%$ of millennials, who grow up in church, have already left. This trend is also visible in other places such as Europe and even South Africa. There are however many people who still have the need to attend church on a Sunday, so they go. Some people do not want to attend church, but they still want an outing on a Sunday, or at least one or other form of an (sometimes, spiritual) experience. The marketplace saw the gap and created a product, like open shopping malls, to address the need.

Therefore, we nowadays see many people flocking to shopping malls on Sunday mornings. Statistics show that they do not really go there only to shop. They do most of their shopping on Saturdays and during the week. They go to the mall or to venues established for recreational purposes to have an experience together with their significant others such as their families or friends (Barmash 2016). Sometimes people want to experience a sense of 
connectedness with the self, or the beyond, in order to have a transcended experience. Therefore, we see that restaurants and coffee shops are packed to full capacity on Sunday mornings. It is family time. People want to spend quality time together. The experience is, thus, functional and recreational. In that sense it becomes a spiritual experience, maybe a post-secular or post-theistic spiritual experience, because they were running and working the whole week, now they use the time to connect, to care, to share stories and experiences and to find and confirm purpose. It might be interpreted as a spiritual, meaningful or purpose-filled experience, and this experience has replaced church for many people. Postmodern, post-secular or post-theistic spirituality is here, in contrast to traditional spirituality, understood as a form of spirituality that appears as an alternative to the spirituality experienced in conventional religion (Ahlbäck 2008).

It refers to the way people outside of the established religions and religious movements handle existential and spiritual issues. Many people of the 21st century do not choose 'readymade' solutions, but in true eclectic spirit themselves decide what they want to believe in, and they create their own combinations and sets of answers, habits and rituals. Postmodern spirituality has an individualistic image. According to Ahlbäck (2008), it is spiritual in the sense of being the opposite of materialistic, and it is intramundane in contrast to extramundane religiosity; it is essentially about what the world is like for the specific individual and how he or she can connect with it and can live in it.

\section{Experiencing products in the marketplace}

The marketplace has created an experience economy, a new economic era in which all businesses must orchestrate memorable events for their customers (Pine \& Gilmore 2014). Future economic growth lies in the value of experiences and transformations. Goods and services are no longer enough. The experience economy offers a creative, highly original and yet eminently practical strategy for companies to script and stage the experiences that will transform the value of what they produce.

Today's consumers are part of the digital generation, and that is an understatement if ever one existed. They are, according to Newman (2015), constantly searching, communicating and checking in. Each action they take, whether they are on their mobile device of choice or at their desktop, they have the same end game: Satisfy me. Give me the answer to my search question. Give me a platform to reach out to those around me. Give me a way to share and explore. Oh, and do all those things immediately, if you don't mind.

As consumers, their interactions with brands are no different. They no longer simply make a purchase and walk away. Consumers seek and often expect additional utility from the brands they patronise. They want to feel like they are listened to. Consumers expect more than goods and services; they need an added experience to connect with the goods and services (Newman 2015).

In the past two decades, the economic offerings of businesses worldwide have become more intentionally experiential (Pine \& Gilmore 2014). This is a fundamental shift in the very fabric of the global economy. Experiences are seen as commercial offerings that engage customers in memorable ways. It offers a distinct form of economic output and as such holds the key to promoting future economic prosperity. Experience has supplanted services as the predominant economic offering in terms of US GDP, as well as employment and actual value. What happens and what people can experience in the marketplace can, therefore, be seen as a strong contestant and competition for the experience that people are getting in church on a Sunday morning.

A lot of industries have also recently created rituals around their products in which the clients participate (Grigorian \& Petersen 2014). The ritual gets created around a myth. Mythtelling is a subtle narration of the story and heritage of the brand and includes a certain degree of mystery. Brands communicate the legends associated with the brand and create a narrative regarding the product. Real people telling real stories about real value is the new currency for brands (Pottie 2014). This narrative is a mixture of facts and fiction with a hint of otherworldly mystery which makes it mythical. Then it becomes something that intrigues the client and the client aspires and longs to acquire it.

The perfume created by Le Labo got it right. Over a period of time all the different fragrances are tested on a woman's skin, then, when she is ready to make a choice, her own unique mixture is hand-blended and individually prepared in front of the lady at the moment of purchase. It then gets placed in a special glass decanter with her name exclusively printed on the bottle. With an expiring date to guarantee exclusivity and originality. Then follows the rest of the ritual. She can take her bottle home, but she has to put it in the fridge and for a whole week she is not supposed to touch it. Something mysterious is happening inside the bottle. The different senses must marry, it must marinate, says the myth, to create a new unique choice of fragrance just for the client (Grigorian \& Petersen 2014). Then, on the seventh day, the bottle can be opened for the first time. The client can start using it, because only then will it start complementing her unique personality the best.

The marketplace has seen that there is a need for experiences, especially experiences connected to something that resembles a ritual or a type of mystery; therefore, some restaurants have also introduced a ritual. Their interior is dark heavy wooden furniture with white damask tablecloths, big white serviettes and expensive glasses and cutlery. They have classical music in the background and waiters dressed like deacons walking up and down. In silence, they serve, with venerable obligingness. Together with loved ones, this experience becomes a sacrament 
for a family. Bread and wine. And we break it and we drink it to strengthen our inner being and as a remembrance. And we see and we taste that it is good.

\section{Experience exclusivity in the marketplace}

Because many people do not belong to church committees and commissions within the inner circles anymore, they still have the need to belong to exclusive circles which give them a sense of status (and power); therefore, the marketplace has created a product. Consumers, especially of luxury brands, are pulled towards the brand with the promise of belonging to an exclusive community. Many consumers may want access to this circle, but only a selected few, who truly share the brand beliefs, can really belong.

Luxury brands create artificial barriers or initiation rituals to select which customers gain admittance. If a customer wants to buy a premium Apple product, all they have to do is pay the price. But many luxury brands steer customers to form a long-term and intimate bond with the brand if they want to be offered the opportunity to buy one of the manufacturer's 'limited edition' products. Customers stay loyal and are rewarded for it. According to Pottie (2014), helping is, therefore, the new selling. The moment you help a customer fulfill a need, you have his or her business. The marketplace fulfils customers' need to belong; therefore, the experience economy is growing.

People can now belong to $4 \times 4$ clubs, elite membership to Mercedes or BMW drivers' societies, to a reading club or a study group. Exclusive gatherings of special people. They want to be part of the group of people who get invited to buy event tickets. Everybody wants to go, but only the selected few gain access. The number of the chosen is limited. Artificial borders, barriers and initiation rituals are created around products and initiation rites get implemented before you can get access to the utmost sanctuary. Rather than putting customers off, this behaviour creates a sense of belonging to a special circle (Grigorian \& Petersen 2014).

To illustrate this, the handbag manufacturer Hermes has created an exclusive handbag called the ' $\mathrm{It}^{\prime}$. But it is not for sale to anybody, even if you have the money. The client needs to first buy a few other Hermes products over a period of time and build a relationship with the brand. Then, after some time, Hermes will 'invite' the customer to purchase the exclusive 'It' (Grigorian \& Petersen 2014). It is seen as a privilege and honour to be invited to buy because then you become part of an exclusive, elected inner circle to whom this product is entrusted. It becomes as spiritual as a house congregation, a cell group, a synodic commission or a pure dogma conservation committee. The brand gives you the promise to belong to an exclusive community.

\section{Experience buildings in the marketplace}

Because there are also still a lot of people who love temples, cathedrals and beautiful church buildings, modern shopping architecture is also moving in that direction. The style of religious architecture provides a sense of identity and experience to people (Verkaaik 2013). There is almost a sacredness even to some shops who borrowed from religious architecture. Architecture has the power to transform. A building can make people feel joy, or sadness, powerful or weak. Nowhere is this truer than in a church, a chapel, synagogue, Buddhist temple or a mosque. For centuries, religion has sparked the design of some of the world's most beautiful buildings.

Luxury brands often achieve this spiritual side of religious buildings by including a degree of mystery or by making a connection with art to communicate myths in an elevated way. Customers have to know that when they step through those doors, they are entering a world that's rare and special. Louis Vuitton has been a master of this, according to Pomerantz (2012). Louis Vuitton surrounds its biggestspending customers in oases of invitation-only luxury, from its wood-panelled New Bond-street store and special VIP second-floor apartment in London to a nautically themed store accessible only by a private jetty in Singapore, where customers on yachts can disembark to pick up items from the latest collections.

Cartier in Sandton, the foyer of six-star hotels, the office building in Jan Shoba Street, Hatfield, Pretoria with its stained windows and chapel shape exterior. The showroom of BMW's branch in Munich, Germany is designed to resemble a cathedral because Germans idolised their vehicles. Customers buy their vehicles from all over Germany, but they prefer that it must be delivered to them from that specific showroom floor because it is special. It is holy and it creates a moment, an experience.

Prada, in combination with AMO research studio in Rotterdam, is located in stores functioning almost like religious temples for discerning customers. It was specially designed by the renowned architect, Rem Koolhaas. Brands like Apple and Nike have similarly transformed their stores into temples in their respective 'Apple Store' and 'Nike Town', as well as the 'Red Bull Station' in Sao Paulo. According to Grigorian and Petersen (2014), the temple is the opportunity that the brand has to physically connect with the customer. More and more stores are being built as places where people can hang out and have coffee with family or friends (Pottie 2014). The days of the big warehouse type of shops are over. Shops are becoming smaller, more personal, with elegant and expensive furniture and decor. 


\section{Discussion and conclusion}

From the statements and information provided above, more questions than answers arise. Questions such as: Can't the church provide its members with the spiritual experience that they are longing for? Is that why many people are not attending any longer? Is that the reason why they are seeking for experiences elsewhere? Is the church aware of the fact that the marketplace is in competition with the church for the same customers in the same time slot?

Who is winning the contest in creating new content for the narrative at the moment? The marketplace is telling the consumer to come and experience. What is the church telling its members? Who is addressing the needs of the people in a satisfactory way?

For an outsider who observes the situation, it seems as if the marketplace provides! The marketplace identified the needs of the consumer. Therefore, the people serve the marketplace with undivided dedication. The boundaries of spirituality have been delimited. Consumers are experiencing deep and meaningful moments where they can connect with each other and with their inner self, in shops, on showroom floors and in restaurants; in $4 \times 4$ clubs, reading circles, cooking classes and wine tasting groups. The search for meaning in life and creating meaningful experiences permeates the world, which automatically includes the marketplace.

And it was evening, and it was morning, and everything in the marketplace was good. And on the seventh day, the customers went for a cappuccino in the coffee shop, and they rested from what they had created during the week.

\section{Acknowledgements Competing interests}

The author declares that he has no financial or personal relationships which may have inappropriately influenced him in writing this article.

\section{References}

Ahlbäck, T., 2008, Postmodern spirituality, Donner Institute, Ăbo.

Barmash, I., 2016, 'Sunday shopping', New York Times.

Cant, M.C. \& Van Heerden, C.H., 2015, Marketing management. A South Africa perspective, Juta, Cape Town.

Church Statistics, 2017, '9 Important Church Statistics For 2017' viewed 27 February 2018, from https://reachrightstudios.com/9-important-church-statistics-2017/

Forman, R.K.C., 2004, Grassroots spirituality: What it is, why it is here, where it is going, Imprint Academic, Charlottesville, VA.

Grigorian, V. \& Petersen, F.E., 2014, 'Designing luxury experience', European Business Review, 21 May, viewed n.d., from http://www.europeanbusinessreview.com/ designing-luxury-experience/

Harari, Y.N., 2011, Sapiens. A brief history of humankind, Vintage, London.

Harari, Y.N., 2016, Homo Deus. A brief history of tomorrow, Vintage, London.

Kale, S., 2006, 'Consumer spirituality and marketing', Asia-Pacific Advances in Consumer Research 7(1), 108-110.

Kuratko, D.F., 2017, Entrepreneurship. Theory, process, practice, Cengage, Boston, MA.

Marcelo, G., 2011, 'Ricœur and the hermeneutics of suspicion', Ricoeur Studies/ Etudes Ricoeuriennes 2(1), 204-209. https://doi.org/10.5195/ERRS.2011.66

Newman, D., 2015, What is the experience economy, and should your business care? Forbes, CMO Network, viewed 28 February 2018, from https://www.forbes.com/ sites/danielnewman/2015/11/24/what-is-the-experience-economy-should-yourbusiness-care/\#6a27d6831d0c

Pine, B.J. \& Gilmore, J.H., 2014, 'A leader's guide to innovation in the experience economy', Strategy and Leadership 42(1), 24-29. https://doi.org/10.1108/SL-092013-0073

Pomerantz, L., 2012, Temples of luxury: How premium brands are using brick and mortar to maintain exclusivity, Forbes, Real Estate, viewed 27 February 2018, from https://www. forbes.com/sites/laurapomerantz/2012/06/18/temples-of-luxury-how-premiumbrands-are-using-brick-and-mortar-to-maintain-exclusivity/\#7ac5b3783199

Pottie, H., 2014, 'If brand is experience, then what makes a good one?', Method, November, viewed 27 February 2018, from https://medium.com/method perspectives/if-brand-is-experience-then-what-makes-a-good-one-370f5d319f08

Van Aarde, A.G., 2009, 'Postsecular spirituality, engaged hermeneutics, and Charles Taylor's notion of hypergoods', HTS Teologiese Studies/Theological Studies 65(1), Art. \#166, 1-8. https://doi.org/10.4102/hts.v65i1.166

Verkaaik, O., 2013, Religious architecture. Anthropological perspectives, Amsterdam University Press, Amsterdam. 